\title{
Sayur Berkah di Masa Pandemi
}

\author{
Chosinawarotin $^{1 *}$, Hendrig Sudrajat ${ }^{2}$ \\ ${ }^{1,2}$ Teknik Sipil, Universitas Islam Balitar, Jl. Majapahit No.2- 4, Kota Blitar, Indonesia, 66137
}

Correspondence: chosinawarotin@unisbablitar.ac.id

Received: 30 Juni 2021 - Revised: 01 Agustus 2021 - Accepted: 16 Agustus 2021

\begin{abstract}
Abstrak. Dilaksanakannya kegiatan pengabdian kepada masyarakat berupa pemberian sayur gratis diharapkan dapat terjalin silaturahmi dan persaudaraan antar sesame sehingga terbentuk rasa kekerabatan antara masyarakat dengan civitas akademik UNISBA Blitar. Adapun tujuan dari kegiatan yang dilakukan ini adalah untuk membantu masyarakat yang terkena dampak Covid-19 dan masyarakat lanjut usia dengan harapan dapat meringankan beban kebutuhan masyarakat. Hasil kegiatan pengabdian ini yaitu proses pembagian sayur gratis dilakukan secara langsung dengan cara menempatan sayur gratis di pinggir jalan yang biasanya dilewati oleh warga. Untuk lebih memudahkan dalam pengambilan,anggota pengabdian menempatkan sayur gratis di jalan dekat mushola yang kemudian setelah selesai jamaah Sholat Asyar masyarakat dengan semangat mengambil sayur gratis yang sudah disediakan.
\end{abstract}

Kata kunci: Sayur hijau, gratis, pandemi, Covid-19

Citation Format: Chosinawarotin \& Sudrajat, H. (2021). Sayur Berkah di Masa Pandemi. Prosiding Seminar Nasional Abdimas Ma Chung (SENAM), xx-xx. 


\section{PENDAHULUAN}

Virus Covid-19 pertama kali diketahui mewabah di Indonesia pada bulan Maret 2020 tepatnya di Jakarta, saat itu terdeteksi ada dua orang warga Depok yang tertural virus Covid-19 dari warga Jepang. Sampai sekarang virus Covid-19 terus meluas di Negara Indonesia dan berbagai Negara lainnya sehingga membuat Pemerintah mengambil langkah-langkah guna menangani penyebaran virus Covid-19 yang diantaranya adalah dikeluarkannya peraturan untuk pembatasan social berskala besar (PSBB) hingga aturan new normal pada masa pandemic Covid-19 (Sidabukke, Tambunan \& Lumbantoruan, 2020).

Mewabahnya virus Covid-19 tentu menimbulkan beberapa dampak bagi sebagian besar masyarakat di Indonesia. Pola kehidupan masyarakat di tengah pandemic Covid-19 mengalami perubahan secara drastic tanpa terkecuali (Sina, 2020). Selain hal tersebut, pandemic virus Covid-19 telah mengakibatkan mobilitas perekonomian berhenti dan secara otomatis kondisi perekonomian di dunia mengalami penurunan tak terkecuali Indonesia. Hal tersebut mengakibatkan banyak bidang industry yang menghentikan aktivitas produksinya sehingga banyak masyarakat yang kehilangan sumber mata pencaharian karena terkena PHK. Kondisi tersebut mengakibatkan sumber pendapatan masyarakat menurun. Masyarakat dengan perekonomian rendah tentu mengalami kesulitan dalam memenuhi kebutuhan hidup sehari-hari yang diantaranya kesulitan membeli bahan pangan karena pendapatan menurun.

Sikap peduli dengan sesame menjadikan manusia yang notaben merupakan makhluk social menjadi terikat dengan orang lain dan apapun yang terjadi terhadap orang tersebut menimbulkan rasa kepedulian (Lorenza \& Swanda, 2020). Individu yang lebih mengutamakan kebutuhan dan perasaan orang lain dibandingkan dengan kepentingannya sendiri merupakan orang yang peduli dan tentunya tidak akan tega untuk menyakiti perasaan orang lain (Purba, 2020). Mereka selalu berusaha untuk menghargai orang lain, berbuat baik kepada sesama, dan membuat orang lain merasa senang. Banyak nilai yang merupakan bagian dari kepedulian social seperti kebaikan, dermawan, perhatian, membantu, dan rasa kasihan.

Kegiatan bakti social merupakan salah satu kegiatan yang mengarah kepada rasa kepedulian sesama manusia guna mewujudkan rasa cinta, rasa saling menolong, rasa saling peduli kepada masyarakat yang membutuhkan uluran tangan dari berbagai pihak. Salah 
satu cabang dari kegiatan bakti social yang merupakan bentuk bagian dari pengabdian masyarakat adalah kegiatan berbagi sembako (Muniarty, Nurhayati, Wulandari, Rimawan \& Amirulmukminin, 2020). Berkaitan dengan kondisi tersebut Dosen Universitas Islam Balitar (UNISBA) melalui kegiatan pengabdian kepada masyarakat yang merupakan bagian dari Tri darma Perguruan Tinggi memberikan bantuan kepada masyarakat terdampak berupa pembagian sayur gratis yang bertujuan untuk membantu meringankan beban masyarakat terdampak Covid-19. Masyarakat terdampak meliputi masyarakat umum khususnya masyarakat dengan usia lebih lanjut dan keluarga yang terkena PHK yang berada di Desa Blimbing. Desa Blimbing merupakan salah satu desa di Kecamatan Tulungagung yang terkena dampak dari Covid-19.

\section{MASALAH}

Mewabahnya virus Covid-19 tentu menimbulkan beberapa dampak bagi sebagian besar masyarakat di Indonesia. Pola kehidupan masyarakat di tengah pandemic Covid-19 mengalami perubahan secara drastic tanpa terkecuali (Sina, 2020). Selain hal tersebut, pandemic virus Covid-19 telah mengakibatkan mobilitas perekonomian berhenti dan secara otomatis kondisi perekonomian di dunia mengalami penurunan tak terkecuali Indonesia. Hal tersebut mengakibatkan banyak bidang industry yang menghentikan aktivitas produksinya sehingga banyak masyarakat yang kehilangan sumber mata pencaharian karena terkena PHK. Kondisi tersebut mengakibatkan sumber pendapatan masyarakat menurun. Masyarakat dengan perekonomian rendah tentu mengalami kesulitan dalam memenuhi kebutuhan hidup sehari-hari yang diantaranya kesulitan membeli bahan pangan karena pendapatan menurun.

Dilaksanakannya kegiatan pengabdian kepada masyarakat berupa pemberian sayur gratis diharapkan dapat terjalin silaturahmi dan persaudaraan antar sesame sehingga terbentuk rasa kekerabatan antara masyarakat dengan civitas akademik UNISBA Blitar. Adapun tujuan dari kegiatan yang dilakukan ini adalah untuk membantu masyarakat yang terkena dampak Covid-19 dan masyarakat lanjut usia dengan harapan dapat meringankan beban kebutuhan masyarakat.

\section{METODE PELAKSANAAN}

Kegiatan pengabdian masyarakat melalui pemberian sayur gratis dilakukan di Desa Blimbing Rejotangan, Kabupaten Tulungagung pada hari Selasa, 15 Juni 2021. Metode yang digunakan yaitu pengabdian kepada masyarakat dalam bentuk pembagian sayur gratis 
kepada masyarakat yang terkena dampak dari Covid-19 dan masyarakat lanjut usia. Dalam melakukan kegiatan pengabdian terdapat beberapa tahapan yang dilakukan yaitu :

1. Tahap persiapan. Pada tahap ini tim pengabdian masyarakat menyiapkan berbagai keperluan yang dibutuhkan dalam pembagian sayur gratis seperti sayur kacang panjang, sayur sop, terong, lauk pauk dan lain-lain yang kemudian dilakukan dengan pengemasan bahan tersebut kedalam plastic agar mudah di ambil dan kemudian dipasang di papan kayu dengan tulisan "Sayur Berkah" di atasnya.

2. Pendistribusian, dalam tahap ini tim pengabdian masyarakat melakukan pendistribusian dengan cara mengumpulkan warga di lokasi pembagian sayur gratis dan mempersialhkan warga mengambil sayur tersebut seperlunya.

\section{HASIL DAN PEMBAHASAN}

Kegiatan pengabdian masyarakat melalui pemberian sayur gratis di lakukan di Desa Blimbing pada hari Selasa, 15 Juni 2021 jam 15.00-selesai. Kegiatan ini dilakukan dalam jangka waktu 1 (satu) hari sesuai undangan yang diberikan tim pengabdian kepada warga Desa Blimbing. Kegiatan ini merupkan bentuk dari kegiatan Pengabdian Masyarakat dalam wujud bakti social pemberian sayur gratis pada masyarakat yang membutuhkan. Sayuran gratis yang dibagikan dipersiapkan secara maksimal degan pengemasan cukup menarik dan tidak lupa untuk mempermudah pengambilan sayur gratis tim pengabdian masyarakat menyiapkan papan kayu yang sudah diberi paku berjajar untuk menggantungkan sayur yang sudah disiapkan untuk diambil warga.

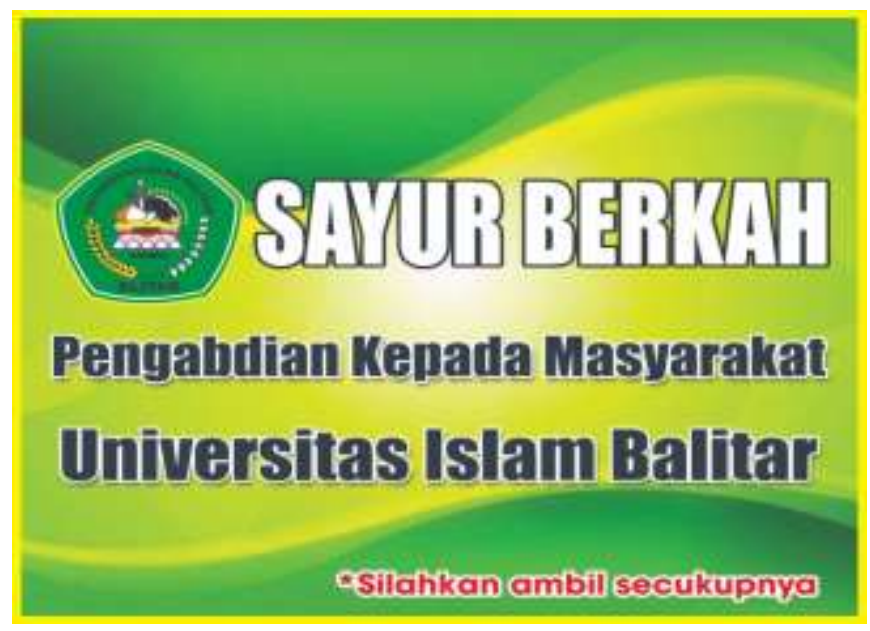

Gambar 1. Desain stiker sayur gratis 


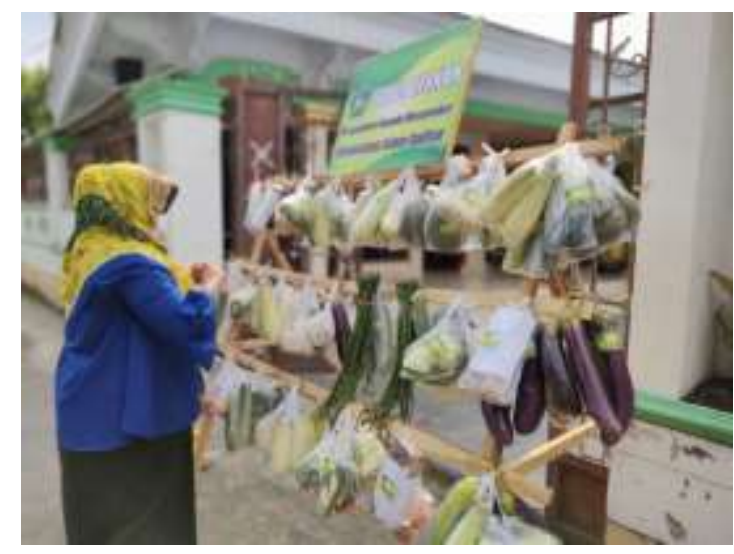

a

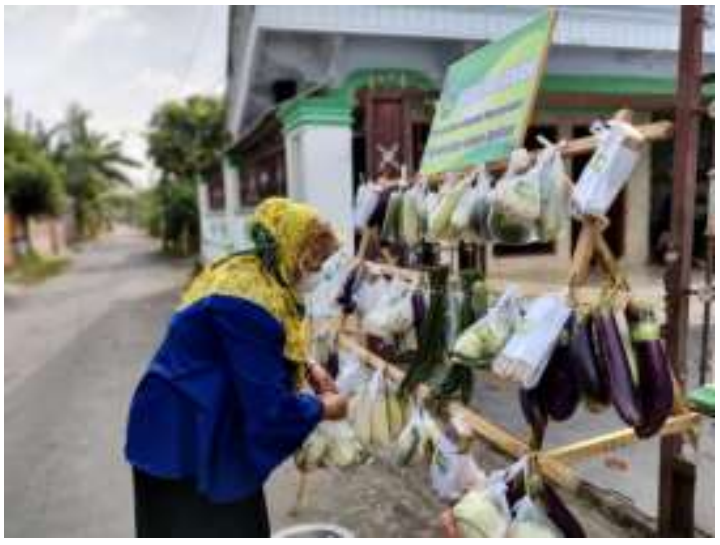

b

Gambar 2. Persiapan pembagaian sayur gratis

Pada tahap pembagian sayur gratis, tim pengabdian kepada masyarakat menggunakan pendekatan partisipatif. Pendekatan partisipatif menekankan kepada pengumpulan data dan proses pelaksanaan yang melibatkan langsung peranan peneliti, dengan cara melihat fenomena lebih luas dan akan disesuaikan dengan kondisi social masyarakat yang tengah diteliti (Rahman, 2019). Pembagian sayur gratis disesuaikan didasarkan pada kondisi masyarakat yang membutuhkan termasuk lansia.

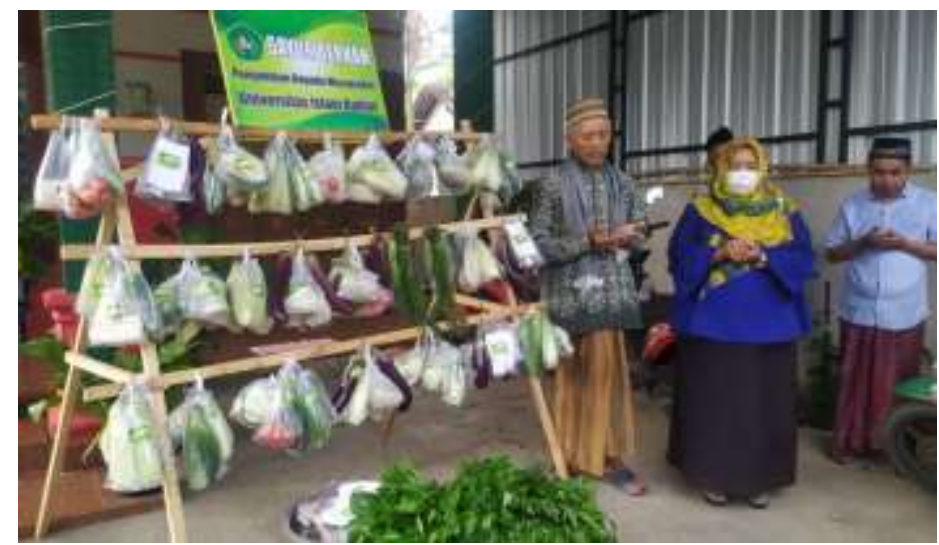

Gambar 3. Doa sebelum pembagian sayur

Proses pembagian sayur gratis dilakukan secara langsung dengan cara menempatan sayur gratis di pinggir jalan yang biasanya dilewati oleh warga. Untuk lebih memudahkan dalam pengambilan,anggota pengabdian menempatkan sayur gratis di jalan dekat mushola yang kemudian setelah selesai jamaah Sholat Asyar masyarakat dengan semangat mengambil sayur gratis yang sudah disediakan. Dengan adanya kegiatan pengabdian 
masyarakat melalui pembagian sayur gratis diharapkan dapat memebrikan manfaat bagi masyarakat apalagi di masa pandemic Covid-19 sungguh kebutuhan masyarakat terbatas dan dikarenakan lemahnya perekonomian sebagai sumber pengahasilan untuk menopang kebutuhan sehari-hari.

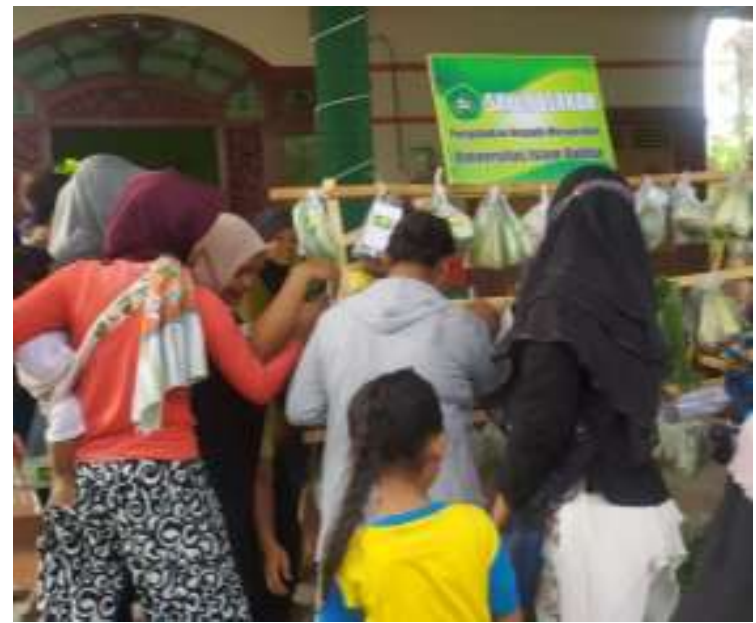

a

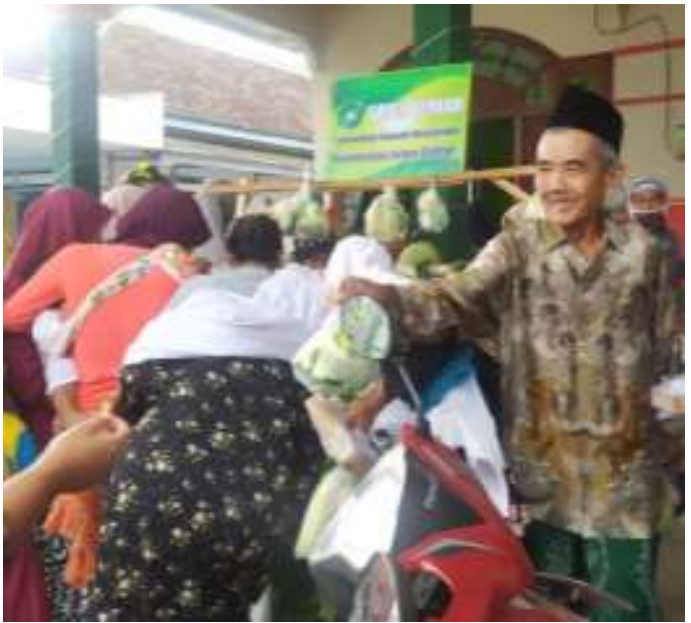

$\mathrm{b}$

Gambar 4. Proses pembagian sayur

\section{KESIMPULAN}

Kegiatan pengabdian kepada masyrakat yang dilakukan oleh Dosen Universitas Islam Balitar melalui pemberian sayur gratis merupakan bentuk peran dari civitas akademika yang berada di tengah masyarakat yang tentunya dapat meringankan kebutuhan masyarakat sekitar yang terkena dampak Covid-19. Kegiatan ini juga berjalan lancar karena dukungan dari warga sekitar yang dengan senang hati memperbolehkan tim pengabdian untuk melakukan kegiatan di Desa mereka. Diharapkan kegiatan pengabdian masyarakat selajutnya yaitu memperluas objek yang akan diberikan sayur gratis dan kerjasama dengan pemerintah setempat sehingga diperoleh pemerataan yang lebih luas lagi.

\section{UCAPAN TERIMA KASIH}

Kami selaku anggota tim pengabdian kepada masyarakat mengucapkan terimakasih kepada Universitas Islam Balitar Blitar yang telah memberikan dana sehingga dapat terlaksananya kegiatan pengabdian kepada masyarakat ini. Kemudian tak lupa kami juga berterimakasih kepada peserta yang telah dengan senang hati mengikuti kegiatan pengabdian ini. 


\section{DAFTAR PUSTAKA}

Lorenza, D. A., \& Suwanda, I. M. (2020). Peran Koordinator Komunitas Bonek Simo Area Surabaya Terhadap Kepedulian Sosial Di Tengah Wabah Covid-19. Kajian Moral dan Kewarganegaraan, 8(3), 1022-1036.

Muniarty, P., Nurhayati, N., Wulandari, W., Rimawan, M., \& Amirulmukminin, A. (2021). Kegiatan Bakti Sosial Melalui Pembagian Sembako Kepada Masyarakat di Pandemi Covid-19. GLOBAL ABDIMAS: Jurnal Pengabdian Masyarakat, 1(1), 18-23.

Purba, A. (2020). Membangun Kepedulian Sosial Di Tengah Wabah Pandemi Covid-19 Sebuah Refleksi Lukas 10: 25-37. Jurnal TEDC, 14(2), 159-164.

Rahman, Arief. (2019). Pendekatan Partisipatif Dalam Pengembangan Komunitas. Modul Pengembangan Komunitas. Bogor: Program Prencanaan dan Pengembangan Komunitas P4W-LPPM Institutue Pertanian Bogor.

Sidabukke, I. R. R., Tambunan, F., \& Lumbantoruan, M. (2020). Pemberian Sembako Dalam Upaya Gerakan Peduli Masyarakat Di Era New Normal Di Desa Medan Estate Kabupaten Deli Serdang. LOGISTA-Jurnal Ilmiah Pengabdian kepada Masyarakat, 4(2), 225-230.

Sina, P. G. (2020). Ekonomi Rumah Tangga Di Era Pandemi Covid-19. Journal of Management: Small and Medium Enterprises (SMEs), 12(2), 239-254.

(C) 2021 by authors. Content on this article is licensed under a Creative Commons Attribution 4.0 International license. (http://creativecommons.org/licenses/by/4.0/). 